Waldemar Zangaro', Jose Marcelo Domingues Torezan', Leila Vergal Rostirola', Priscila Bochi de Souza', Marco Antonio Nogueira ${ }^{2}$

\title{
INFLUENCE OF MYCORRHIZAS, ORGANIC SUBSTRATES AND CONTAINER VOLUMES ON THE GROWTH OF Heliocarpus popayanensis Kunth
}

Keywords:

inoculation

Glomeromycota

nursery

plant growth depression

tropical native woody specie

Histórico:

Recebido 04/I I/201 I

Aceito 08/04/2015

Palavras chave: depressão no crescimento espécie arbórea tropical

Glomeromycota inoculação dreno de carbono viveiro de mudas

Correspondence: wzangaro@uel.br

DOI: I0.1590/0 I047760201521031335
ABSTRACT: This work assessed, under nursery conditions, the effect of arbuscular mycorrhizal fungi (AMF) inoculation on the initial growth of the woody species Heliocarpus popayanensis Kunth in containers of different sizes (nursery tubes of 50 or $250 \mathrm{~cm}^{3}$ ) containing composted cattle manure or organic Pinus spp bark compost diluted ( 0 to $100 \%$, each $9 \%$ ) with low fertility soil. Plants in cattle manure grew more than plants grown in pine bark manure independent of tube size. AMF were more efficient in improving plant growth in $250 \mathrm{~cm}^{3}$ tubes than in $50 \mathrm{~cm}^{3}$ tubes independent of the substrates. Mycorrhizal plants grown in $50 \mathrm{~cm}^{3}$ tubes showed less growth than non-mycorrhizal ones irrespective of the substrates. Nevertheless, this growth depression decreased with an increase of substrates dilution with low fertility soil. In the higher dilutions, growth depression did not occur and there was a positive response to AMF inoculation. In addition, only mycorrhizal plantlets showed some growth in low fertility soil as the sole substrate. These results indicated that AMF affect plantlet growth positively or negatively depending on the combination of substrates, fertility level, and container size.

\section{INFLUÊNCIA DE MICORRIZAS, SUBSTRATOS ORGÂNICOS E VOLUME DE RECIPIENTES PARA O CRESCIMENTO DE Heliocarpus popayanensis KUNTH}

RESUMO: Em condições de viveiro de mudas, foram avaliados os efeitos da inoculação de fungos micorrízicos arbusculares (FMA) no crescimento inicial da espécie arbórea Heliocarpus popayanensis Kunth em recipientes (tubetes) com 50 ou $250 \mathrm{~cm}^{3}$, contendo substrato a base de esterco de gado ou composto comercial a base de casca de Pinus spp, que foram diluídos com solo de baixa fertilidade (0 para 100\% e intervalo de $9 \%$ ). As plântulas apresentaram maior crescimento em composto a base de esterco de gado do que no composto a base de casca de Pinus, independente do volume do recipiente. Os FMA foram mais eficientes em melhorar o crescimento das plântulas nos tubetes de 250 $\mathrm{cm}^{3}$ do que em $50 \mathrm{~cm}^{3}$, independente do substrato utilizado. Plântulas crescidas com FMA nos tubetes de $50 \mathrm{~cm}^{3}$ apresentaram menor crescimento do que aquelas crescidas sem FMA, independente do substrato. Porem, esta depressão no crescimento das plântulas com FMA diminuiu quando a diluição dos substratos foi aumentada com solo de baixa fertilidade. A depressão não ocorreu quando os substratos foram mais diluídos e houve resposta positiva para a inoculação com FMA. Os resultados indicam que os FMA afetam o crescimento das plântulas de maneira positiva ou negativa dependendo da combinação do tipo de substrato, dos níveis de fertilidade e do volume do recipiente de cultivo.

' UEL, Londrina, Paraná, Brasil

2 EMBRAPA, Londrina, Paraná, Brasil 


\section{INTRODUCTION}

The nursery production system is an important factor in determining seedling quality and field performance. Higher seedling mortality can be observed in some situations because of low seedling quality (VANDRESEN et al., 2007). A quality seedling must have a well-developed root system in suspended tubes with adequate substrate. Organic and synthetic substrates and a mixture of both have been used for growing seedlings of native woody species in Brazilians nurseries. However, such substrates, commonly lack arbuscular mycorrhizal fungi (AMF) propagules (SAGGIN-JUNIOR; LOVATO, 1999). These fungi are considered an important biotic factor that influence the establishment and growth of native species of different successional stages (ZANGARO et al., 20I2a). To establish symbiosis, the inoculation with AMF must be attempted during early seedling development (ZANGARO et al., 2009). Inoculated seedlings can show higher growth rates, lower resource needs, and may be more tolerant to transplanting stress, which are key features in the restoration of degradated areas (VANDRESEN et al., 2007). The mutualism that characterises the relationship between fine roots and AMF provides the host plant with improved development, mainly because of a higher nutrient absorption (mostly phosphorus) and a higher resistance to water stress and soil pathogens $(\mathrm{LYNCH}$; HO, 2005, ZANGARO et al. 2002).

High-quality plantlets are crucial for the success of restoration programmes and the use of some soil microorganisms as biofertilizers can be helpful for this purpose. The establishment and survival of pioneer woody species in open and disturbed tropical areas have been attributed to their high degree of mycotrophy and responsiveness to AMF (ZANGARO et al., 20I3, 20I4). Knowledge of how tree species can establish symbiosis with AMF and the benefits generated is one of the keys to the problem of producing seedlings for successful forest ecological restoration (ZANGARO et al., 20I2b).

The cultivation pot volume is an important characteristic to be taken into account to optimize the seedling production spaces in nurseries, and some studies show that the benefits obtained by plants via mycorrhizal symbiosis may differ with the size of cultivation pot (BÅÅTH, HAYMAN, 1994; CARDOSO et al., 2004;
AUDET, CHAREST, 20I0). However, these studies did not use native tropical woody species and were not focused on the nursery production.

In this context, the present work aimed to investigate the seedling growth of the tropical tree species Heliocarpus popayanensis Kunth (Malvaceae) with or without AMF inoculation in different tube size and substrates, for production of high quality plantlets in nursery. This plant specie was select because is a mycotrophic tropical pioneer tree, frequently used in forest restoration activities because of its fast growth rate and high drought tolerance (VANDRESEN et al., 2007).

\section{MATERIALS AND METHODS}

Seedlings of Heliocarpus popayanensis were grown in two main substrates: one with organic cattle manure compost (prepared in the lab) and another with organic Pinus spp bark compost (commercially obtained). The organic cattle manure was selected because is very abundant and commonly utilized as substrate for plant growth in nurseries. Both substrates were diluted with low fertility subsoil, inoculated or not with AM fungi, and used to fill 50 and $250 \mathrm{~cm}^{3}$ nursery tubes. The organic cattle manure was composted in $2-3 \mathrm{~m}^{3}$ piles for 90 days and sieved before use. Commercial substrate (Mecplant ${ }^{\circledR}$ ) was composed of Pinus spp bark and vermiculite (I:I, v, v) and soluble fertiliser (I33 g N, 687 $\mathrm{g} \mathrm{P}_{2} \mathrm{O}_{5}, 233 \mathrm{~g} \mathrm{~K}_{2} \mathrm{O}$ per $\mathrm{m}^{3}$ of substrate). Both organic substrates were manipulated carefully for avoid AMF contamination and were not sterilised in autoclave to avoid the release of toxic compounds when heated. Low fertility soil was obtained from subsoil excavations in the university campus and sterilised in an autoclave with vapour stream for three days for AMF elimination. The nursery tubes used for seedlings production were two types of rigid re-usable plastic containers which were of circular shape, tapered from top to bottom, with interior vertical anti-spiralling ribs and an open crossed base. The small tubes were $50 \times 10^{3} \mathrm{~mm}^{3}$ in volume and $120 \mathrm{~mm}$ in depth whereas the large tubes were $250 \times 10^{3} \mathrm{~mm}^{3}$ in volume and $200 \mathrm{~mm}$ in depth. Organic substrates were diluted $(0-100 \% \mathrm{v} / \mathrm{v}$, in $9 \%$ intervals) with a mixture of $90 \%$ subsoil and $10 \%$ washed sand (Table I). 
TABLE 1 Substrates dilution (v/v), from Cattle Manure Compost (CMC) and commercial Pinus spp Bark Compost (PBC).

TABELA 1 Diluição dos substratos (v/v), composto a base de esterco de gado (CMC) e Pinus spp comercial (PBC).

\begin{tabular}{cc}
\hline CMC + subsoil & PBC + subsoil \\
\hline $100 \%+0 \%$ & $100 \%+0 \%$ \\
$90.9 \%+9.1 \%$ & $90.9 \%+9.1 \%$ \\
$81.8 \%+18.2 \%$ & $81.8 \%+18.2 \%$ \\
$72.7 \%+27.3 \%$ & $72.7 \%+27.3 \%$ \\
$63.6 \%+36.4 \%$ & $63.6 \%+36.4 \%$ \\
$54.5 \%+45.5 \%$ & $54.5 \%+45.5 \%$ \\
$45.5 \%+54.5 \%$ & $45.5 \%+54.5 \%$ \\
$36.4 \%+63.6 \%$ & $36.4 \%+63.6 \%$ \\
$27.3 \%+72.7 \%$ & $27.3 \%+72.7 \%$ \\
$18.2 \%+81.8 \%$ & $18.2 \%+81.8 \%$ \\
$9.1 \%+90.9 \%$ & $9.1 \%+90.9 \%$ \\
$0 \%+100 \%$ & $0 \%+100 \%$ \\
\hline
\end{tabular}

Diluted organic substrates were used to fill the nursery tubes, which were randomly distributed in 10 tube groups in suspended plates. In half of the tubes, 2.0 $g$ of fresh crude AMF inoculum were mixed at the top of the substrate. Such inoculum was a mixture of native AMF species containing approximately 950 spores plus hyphae and colonized roots. This crude inoculum was obtained from the rhizosphere of the pioneer native woody species Cecropia pachystachya grown in pot culture; it consisted of spores of different native AMF species obtained in a 10 years-old secondary forest. Glomus macrocarpum, Glomus clavisporum, Claroideoglomus etunicatum, Acaulospora morrowiae, Glomus invermaium and Funneliformis geosporus were the more abundant AMF species after inoculum preparation.

The dilution series, different tube sizes, and AMF inoculation resulted in 48 inoculated and 48 noninoculated treatments. For each dilution and tube size, 10 replicates with and without inoculation were prepared. Four $H$. popayanensis seeds per tube were inserted at $0.5 \mathrm{~cm}$ depth. After germination, only one seedling per tube was retained. The experiment was carried out in the summer (January to March) in nursery conditions under a $50 \%$ Sombrite ${ }^{\circledR}$ mesh and micro-aspersion irrigation four times a day, 20 min per time. Seedlings were grown for three months and five seedlings from each treatment were randomly selected, carefully washed in water, the root and shoot separated, dried $\left(60^{\circ} \mathrm{C}\right)$, and weighed.
For each sample, I $g$ of fresh fine roots of approximately $\mathrm{I} \mathrm{cm}$ length were fixed in FAA $(5 \mathrm{~mL}$ formaldehyde, $5 \mathrm{~mL}$ acetic acid, $90 \mathrm{~mL}$ ethanol $50 \%$ ) and stored. For mycorrhizal colonization, fine roots were cleared in $10 \% \mathrm{KOH}$, acidification with $1 \% \mathrm{HCl}$, washing in tap water and staining with $0.05 \%$ trypan blue in lactoglycerol solution (BRUNDRETT et al., 1996). The total AMF colonization was calculated by the grid-line intersection method under $100 \times$ magnifications.

The procedures for substrates chemical determination were calcium and magnesium extracted with I $\mathrm{M} \mathrm{KCl}$ and determined by titration. Phosphorus and potassium were extracted using Mehlich-I and determined using colorimetry and flame photometry, respectively. Nitrogenous was extracted with $2 \mathrm{M} \mathrm{KCl}$, followed by semi-micro Kjeldahl distillation and titration.

For data analyses, shoot and root dry mass of each treatment of the soil dilution level was compared using Student's t-test. Data of AMF root colonization were transformed from the arcsine of square root values before analysis and were compared using ANOVA and Tukey test with $p \leq 0.05$ set as the significance threshold.

\section{RESULTS AND DISCUSSION}

Nutrients were in higher concentrations in the cattle manure compost than in the commercial Pinus spp bark compost (Table 2). The subsoil utilised in the dilution series showed an overall low nutrient content, thereby validating its use as a dilution material.

Shoot dry mass (Figure I) and root dry mass (Figure 2) were all higher for plants growing in the $250 \mathrm{~cm}^{3}$ than in the $50 \mathrm{~cm}^{3}$ tubes, independently of the substrate type and AMF inoculation. Otherwise, the cattle manure compost resulted in higher shoot and root growth than the Pinus bark compost regardless of the tube volume, and non-inoculated plants exhibited decreased shoot dry mass and root dry mass as the substrate dilution increased.

The averages of AMF root colonization (Figure 3 ) were $64.6 \%$ for cattle manure and $58.7 \%$ for Pinus bark composts in the $250 \mathrm{~cm}^{3}$ tubes and $55.3 \%$ and $52.1 \%$, respectively, in the $50 \mathrm{~cm}^{3}$ tubes. The AMF root colonization was not detected in the majority of non-inoculated treatments in both types of substrates and tube sizes. A very small number of AMF colonization events were observed solely in some roots of the noninoculated treatments of the cattle manure compost from 91,73 and $18 \%$ dilutions in the $250 \mathrm{~cm}^{3}$ tubes and 54 and $36 \%$ dilutions in the $50 \mathrm{~cm}^{3}$ tubes. 
TABLE 2 Nutrient concentration in different substrates ( $\pm S D, n=5)$.

TABELA 2 Concentração de nutrientes nos diferentes substratos ( $\pm D P, n=5)$.

\begin{tabular}{cccc}
\hline & Subsoil & Pinus spp bark compost & Cattle manure compost \\
\hline $\mathrm{pH}\left(\mathrm{Ca} \mathrm{Cl}_{2}\right)$ & $5.0 \pm 0.8$ & $5.6 \pm 0.6$ & $6.8 \pm 0.3$ \\
$\mathrm{~N}\left(\mathrm{mg} \cdot \mathrm{kg}^{-1}\right)$ & $4.2 \pm 0.4$ & $23.3 \pm 9.6$ & $136.2 \pm 32$ \\
$\mathrm{P}\left(\mathrm{mg} \cdot \mathrm{kg}^{-1}\right)$ & $1.9 \pm 0.4$ & $6.5 \pm 1.8$ & $28.2 \pm 5.9$ \\
$\mathrm{Ca}\left(\mathrm{mg} \cdot \mathrm{kg}^{-1}\right)$ & $4.3 \pm 0.9$ & $62.4 \pm 44.2$ & $205.4 \pm 56$ \\
$\mathrm{Mg}\left(\mathrm{mg} \cdot \mathrm{kg}^{-1}\right)$ & $2.2 \pm 0.7$ & $28.3 \pm 11.6$ & $69.7 \pm 30.1$ \\
$\mathrm{~K}\left(\mathrm{mg} \cdot \mathrm{kg}^{-1}\right)$ & $0.5 \pm 0.2$ & $9.7 \pm 2.3$ & $73.9 \pm 32.8$ \\
\hline
\end{tabular}
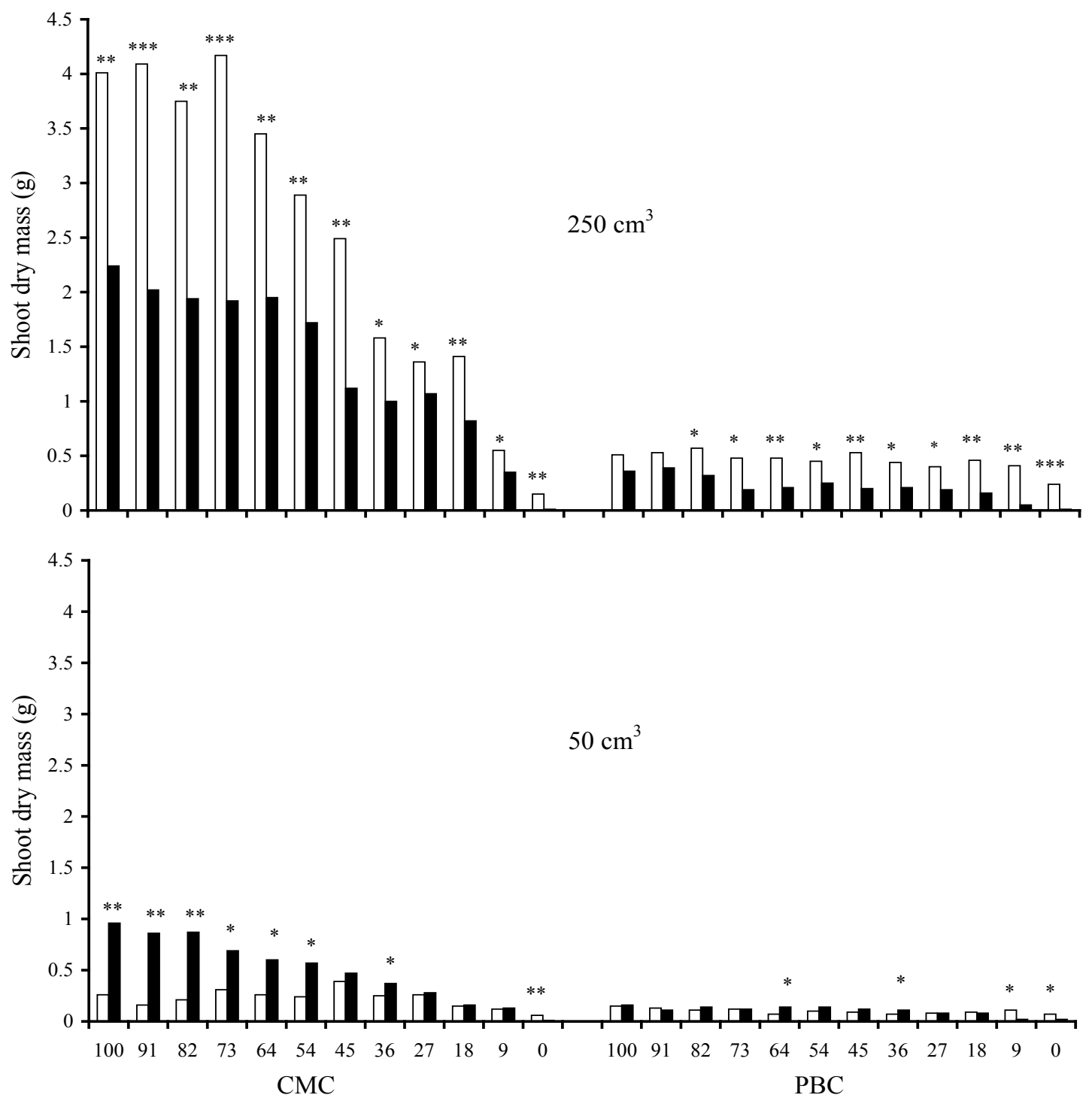

FIGURE 1 Shoot dry mass of $H$. popayanensis seedlings inoculated $(\square)$ and non-inoculated ( $(\mathbf{)})$ with AMF, grown in cattle manure compost (CMC) and Pinus bark compost (PBC) with different dilution percentage (as presented in Table I), in 250 $\mathrm{cm}^{3}$ and $50 \mathrm{~cm}^{3}$ tubes. **** $\mathrm{P}<0.001$, *** $\mathrm{P}<0.01$, $* \mathrm{P}<0.05$, Student's test.

FIGURA 1 Massa seca da parte aérea de plântulas de $H$. popayanensis inoculadas ( $\square$ ) e não inoculadas (ロ) com FMA, crescidas em composto a base de esterco de gado (CMC) e composto de Pinus (PBC) com diferentes percentagens de diluição (apresentado na Tabela I), em tubos de $250 \mathrm{~cm}^{3}$ e $50 \mathrm{~cm}^{3}$. ${ }^{*} * * * 0.00$ I, $* * * P<0.01$, * $\mathrm{P}<0.05$ do teste de Student. 

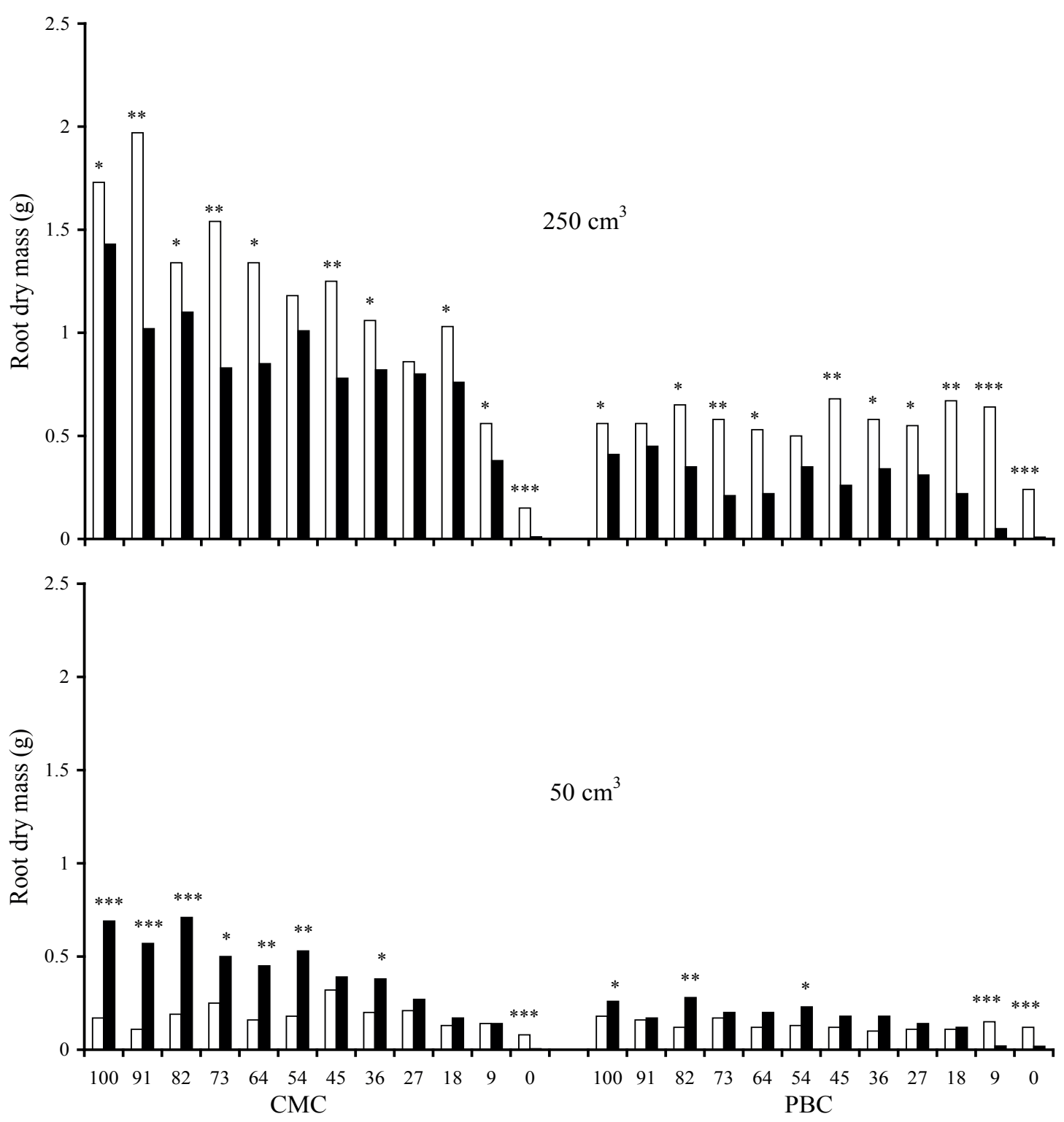

FIGURE 2 Root dry mass of $H$. popayanensis seedlings inoculated ( $\square$ ) and non-inoculated ( $\square$ ) with AMF, grown in cattle manure compost (CMC) and Pinus bark compost (PBC) with different dilution percentage (as presented in Table I), in 250 $\mathrm{cm}^{3}$ and $50 \mathrm{~cm}^{3}$ tubes. $* * * * P<0.001$, *** $\mathrm{P}<0.0 \mathrm{I}$, $* \mathrm{P}<0.05$, Student test.

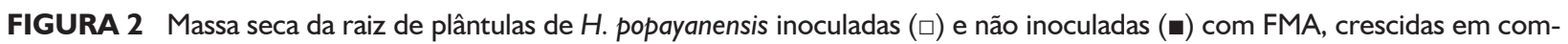
posto a base de esterco de gado (CMC) e a base de casca de Pinus (PBC) com diferentes percentagens de diluição (apresentado na Tabela I), em tubos de $250 \mathrm{~cm}^{3}$ e $50 \mathrm{~cm}^{3}$. ***** $\mathrm{P}<0.00$ I, *** $\mathrm{P}<0.0 \mathrm{I}$, * $\mathrm{P}<0.05$ do teste de Student.

As expected the plant performance was better in $250 \mathrm{~cm}^{3}$ than $50 \mathrm{~cm}^{3}$ tubes volume in both substrates, since the root growth restriction is stronger in pots with small volume, as consequence, a low shoot growth is achieved (AUDET; CHAREST, $2010)$. In the $250 \mathrm{~cm}^{3}$ tubes, AMF inoculation resulted in higher shoot and root mass for plants in both types of substrates and dilutions. In most of the cases, shoot and root biomasses were significantly higher in inoculated treatments than in non-inoculated ones. On the contrary, in $50 \mathrm{~cm}^{3}$ tubes, AMF inoculation resulted in lower shoot and root mass regardless of the type of substrate. This result points to an important negative effect of AMF inoculation under this experimental condition. 

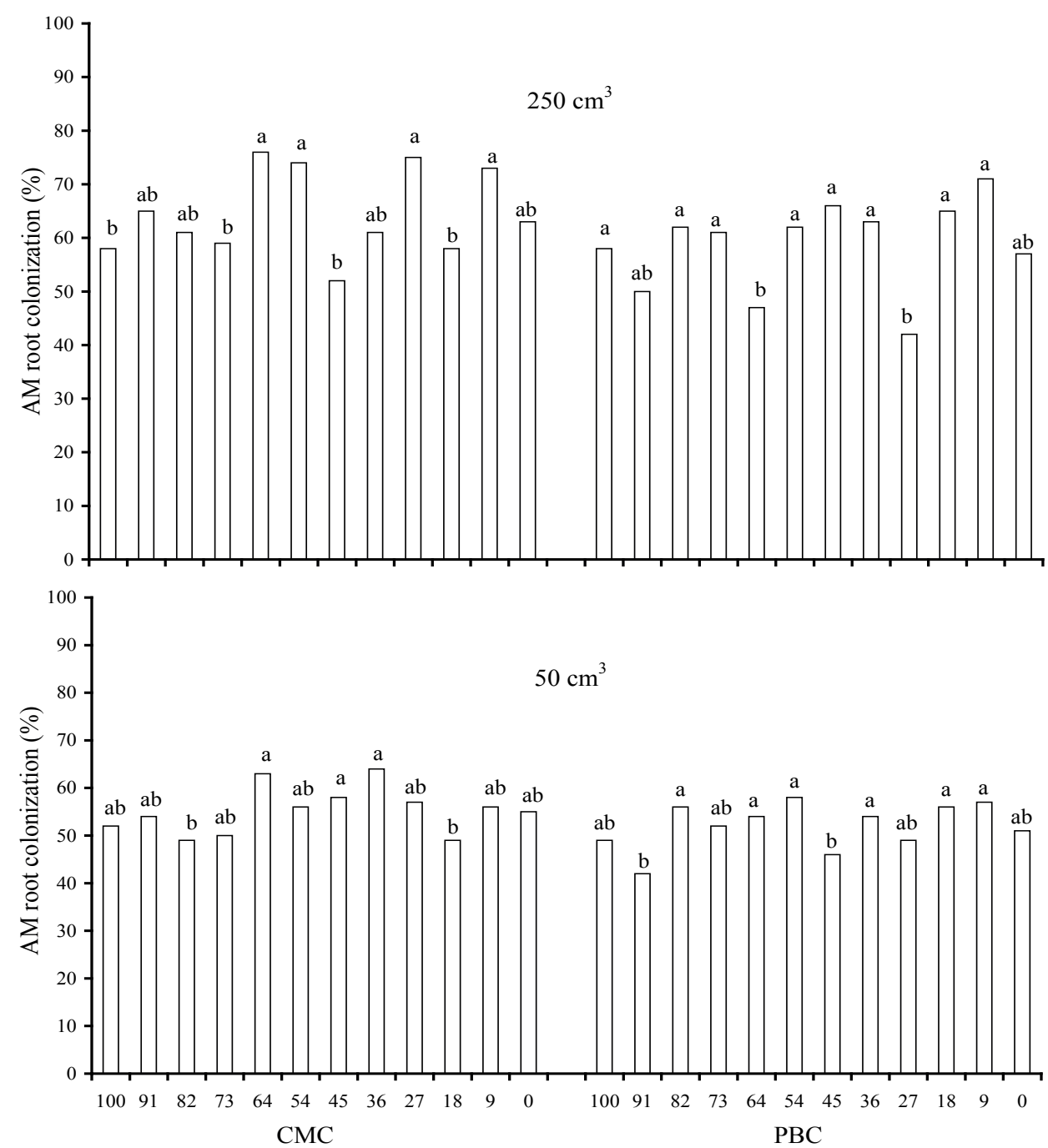

FIGURE 3 AMF root colonization of $H$. popayanensis seedlings grown in cattle manure compost (CMC) and Pinus bark compost (PBC) with different dilution percentage (as presented in Table I), in 250 $\mathrm{cm}^{3}$ and $50 \mathrm{~cm}^{3}$ tubes. Means followed by the same letter are not different by Tukey test at $5 \%$.

FIGURE 3 Colonização micorrízica das plântulas de $H$. popayanensis, crescidas em composto a base de esterco de gado (CMC) e casca de Pinus spp (PBC) com diferentes percentagens de diluição (apresentado na Tabela I), em tubos de $250 \mathrm{~cm}^{3}$ e $50 \mathrm{~cm}^{3}$. Médias seguidas pela mesma letra não diferem pelo teste de Tukey a $5 \%$.

Influence of AMF on plant growth in different substrate types and tube sizes

Non-inoculated $H$. popayanensis seedlings, in both substrate types and both tube sizes, showed root and shoot growth reduction in the same proportion as dilution with low fertility subsoil. Nearly $50 \%$ dilution resulted in a $50 \%$ growth reduction, demonstrating that dilution caused a proportional reduction in fertility, and that in the absence of AMF, plant growth was directly related to soil fertility. By contrast, under AMF inoculation treatments, most of the growth parameters measured were strongly modified, leading to the lack of any relationship between growth and substrate fertility, demonstrating the strong influence (both positive or negative) of AMF on plant growth in all substrates and tube volume combinations. Moreover, in pure subsoil, the seedlings did not grow without AMF. All these results agree with other reports for tropical pioneer tree species, which usually show a high degree of responsiveness to AMF and its vital importance for plant survival in low fertility conditions (PASQUALINI 
et al., 2007, ZANGARO et al., 2005, 2007).

Seedlings grown in cattle manure compost in $250 \mathrm{~cm}^{3}$ tubes, with or without AMF, showed a better performance than plants from all other treatments. Inoculation caused positive effect on plants in almost all manure compost and $250 \mathrm{~cm}^{3}$ tube treatments, but better results were achieved in treatments with more than $50 \%$ manure compost. Seedlings inoculated with AMF growing in the Pinus spp bark compost (commercial substrate) in $250 \mathrm{~cm}^{3}$ tubes showed a positive response to inoculation. Better growth and biomass production were obtained with higher dilutions of the compost with subsoil (less fertile combinations) with AMF inoculation. However, regardless of whether seedlings were inoculated or not, growth in the Pinus spp bark compost combinations were smaller than those observed using the manure compost.

Contrasting with the results obtained with the $250 \mathrm{~cm}^{3}$ tubes, plants inoculated with AMF from 50 $\mathrm{cm}^{3}$ tubes showed growth depression. Treated plants grown in using 40 to $100 \%$ of manure compost and less diluted Pinus bark compost display strong growth depression in inoculated seedlings. This depression was stronger in more fertile substrates combinations. Otherwise, the negative effect of symbiosis on host plants was much smaller in the Pinus bark compost than the manure compost. Hence, the relative cost of symbiosis for plant host was higher in small volume and high fertility substrates combinations.

\section{AMF association cost for host plant}

Plant species colonized by AMF may experience a growth depression under high $P$ availability (SMITH; READ, 2008) and AMF might impair plant growth if the costs of the symbiosis are higher than the benefits for plant nutrient uptake (KOIDE, 1985, KASCHUK et al., 2009). Bååth e Hayman (1984) reported that growth response decreased when onion plants were grown inoculated with AMF in small volume pots than pots with larger volume. Such growth decrease was attributed to nutrient competition between plant roots and AMF hyphae in the small soil volume. Growth depression also occurs when the cost of carbon drained by fungi from the plant exceeds the benefits of nutrient uptake via AMF (NOGUEIRA; CARDOSO, 2006, LI et al., 2008, KASCHUK et al., 2009). The benefits of this plant-fungus association can also be reduced by light limitation that decrease the photosynthetic rate and consequently the carbon allocation to maintain the symbiosis (GEHRING, 2003, SMITH; READ, 2008), as long as carbon drainage by fungi ranges from 5 to $37 \%$ of total daily photosynthetic product (PENG et al., 1993, NIELSEN et al., 1998, LYNCH; HO, 2005).

The growth depression observed in $H$. popayanensis probably represents the cost of symbiosis, since AMF are obligate symbionts and may require large amounts of photosynthetic products. Growth depression, caused by AMF probably for carbon drain, was higher in low volume tubes with high fertility than in those with low fertility substrates, and a competition for nutrients between fungi and plants probably was established (BÅ̊̊TH, HAYMAN, 1984). Since plant species with a high degree of response to AMF can be colonized very fast and have a high root colonization rate, carbon drained by fungi can be very high (GRAHAM; EISSENSTAT, 1994, RONDINA et al., 2014). Seedlings of $H$. popayanensis inoculated with AMF and grown in more fertile substrates in $50 \mathrm{~cm}^{3}$ tubes displayed growth depression and high root colonization. This AMF colonization level probably imposes a high carbon drain to the plant because the low container volume limits the root expansion and nutrient acquisition, leading to AMF symbiosis cost greater than its benefits, causing plant growth depression that remained during the entire experiment.

On the other hand, in $250 \mathrm{~cm}^{3}$ tubes, the abundant root expansion and the higher levels of AMF colonization may have resulted in a better plant nutritional status. So the plant's photosynthetic potential and carbon translocation to roots increases, allowing for higher levels of AMF colonization (GAMAGE et al., 2004, SMITH; READ, 2008, KASCHUK et al., 2009). In this case, AMF symbiosis cost was smaller than its benefits to the host plant. However, Grace et al. (2009) reported that both high and low levels of root colonization by two species of AMF resulted in similar growth depression in barley plants. The authors suggested that the plant growth depression could not be attributed solely to carbon loss for AMF in high levels of root colonization, but also that low levels of AMF may have contributed to decrease $P$ uptake by host plant via root epidermis and root hairs. In the present study, it is clear that the higher AMF colonization levels make the cost of symbiosis higher than its benefits to the host plant in small size tubes and high fertility substrates. 
Growth depression was not observed in seedlings grown with AM fungi in nutrient-poor substrates and small size tubes, where seedlings showed a positive response to AMF colonization. In nutrient-poor substrates and without AMF, seedlings did not grow, probably because the fine roots could not ensure adequate nutrition to maintain their inherently fast growth rate. In this case AMF root colonization became indispensable for both nutrient acquisition and plant survival (ZANGARO et al., 2008, 2013).

In summary, to improve the production of high quality seedlings of tropical pioneer trees and avoid growth depression in nurseries, one must consider the combination of higher volume pots or tubes, pure or diluted (up to $50 \%$ with subsoil) manure compost, and AMF inoculation. In this context, fertilisation is unnecessary. Pure commercial Pinus spp bark compost was unsuitable for seedling production, and fertilisation must be used.

\section{REFERENCES}

AUDET, P.; CHAREST, C. Identification of constraining experimental-design factor in mycorrhizal pot-growth studies. Journal of Botany, ID7I80I3, 20I0. doi: I0.I I55/20I0/7I80I3. 2010.

BÅÅTH, E.; HAYMAN D. S. Effect of soil volume and plant density on mycorrhizal infection and growth response. Plant and Soil, v. 77, p. 373-376, 1984.

BRUNDRETT, M.; BEEGHER, N.; DELL, B.; GROOVE, T.; MALAJCZUK, N. Working with mycorrhizas in forestry and agriculture. Canberra, ACIAR Monograph, 1996. $374 p$.

CARDOSO, I. M.; BODDINGTON, C. L.; JANSSEN, B. H.; OENEMA, O.; KUYPER, T. W. Double pot and double compartment: integrating two approaches to study nutrient uptake by arbuscular mycorrhizal fungi. Plant and Soil, v. 260, p. 30I-310, 2004.

GAMAGE, H. K.; SINGHAKUMARA, B. M. P.; ASHTON, M. S. Effects of light and fertilization on arbuscular mycorrhizal colonization and growth of tropical rain-forest Syzygium tree seedlings. Journal of Tropical Ecology, v. 20, p. 525534, 2004.

GEHRING, C. A. Growth responses to arbuscular mycorrhizas by rain forest seedlings vary with light intensity and tree species. Plant Ecology, v. 167, p. I27-139, 2003.
GRACE, E. J.; COTSAFITS, O.; TESTER, M.; SMITH, F. A.; SMITH, S. E. Arbuscular mycorrhizal inhibition of growth in barley cannot be attributed to extent of colonization, fungal phosphorus uptake or effects on expression of plant phosphate transporter genes. New Phytologist, v. I8I, p. 938-949, 2009.

GRAHAM, J. H.; EISSENSTAT, D. M. Host genotype and the formation and function of VA mycorrhizae. Plant and Soil, v. 159, p. 179-185, 1994.

KASCHUK, G.; KUYPER, T. W.; LEFFELAAR, P. A.; HUNGRIA, M.; GILLER, K.E. Are the rates of photosynthesis stimulated by the carbon sink strength of rhizobial and arbuscular mycorrhizal symbioses? Soil Biology and Biochemistry, v. 4I, p. I233-I244, 2009.

KOIDE, R. The nature of growth depressions in sunflower caused by vesicular-arbuscular mycorrhizal infection. New Phytologist, v. 99, p. 449-462, 1985.

LI, H.; SMITH, F. A; DICKSON, S.; HOLLOWAY, R. E.; SMITH, S. E. Plant growth depressions in arbuscular mycorrhizal symbioses: not just caused by carbon drain? New Phytologist, v. I 78, p. 852-862, 2008.

LYNCH, J. P.; HO, M. D. Rhizoeconomics: Carbon costs of phosphorus acquisition. Plant and Soil, v. 269, p. 45-56, 2005.

NIELSEN, K. L.; BOUMA, T. J.; LYNCH, J. P.; EISSENSTAT, D. $M$. Effects of phosphorus availability and vesicular-arbuscular mycorrhizas on the carbon budget of common bean (Phaseolus vulgaris). New Phytolologist, v. 139, p. 647-656, 1998.

NOGUEIRA, M. A.; CARDOSO, E. J. B. N. Plant growth and phosphorus uptake in mycorrhizal rangpur lime seedlings under different levels of phosphorus. Pesquisa Agropecuária Brasileira, v. 4I, p. 93-99, 2006.

PASQUALINI, D.; UHLMANN, A.; STÜRMER, S. L. Arbuscular mycorrhizal fungal communities influence growth and phosphorus concentration of woody plants species from the Atlantic rain forest in South Brazil. Forest Ecology and Management, v. 245, p. I48-I55, 2007.

PENG, S.; EISSENSTAT, D. M.; GRAHAM, J. H.; WILLIAMS, K.; HODGE, N. C. Growth depression in mycorrhizal citrus at high-phosphorus supply: analysis of carbon costs. Plant Physiology, v. 101, p. 1063-1071, 1993.

RONDINA, A. B. L.; LESCANO, L. E. A. M.; ALVES, R. A.; MATSUURA, E. M.; NOGUEIRA, M. A.; ZANGARO, W. Arbuscular mycorrhizas increase survival, precocity and 
flowering of herbaceous and shrubby species of early stages of tropical succession in pot cultivation. Journal of Tropical Ecology, v. 30, p. 599-6I4, 2014.

SAGGIN-JÚNIOR, O. J.; LOVATO, P. E. Aplicação de micorrizas arbusculares na produção de mudas e plantas micropropagadas. In: SIQUEIRA, J. O.; MOREIRA, F. M. S.; LOPES, A. S.; GUILERME, L. R. G.; FAQUIM, V.; FURTINI, A. E.; CARVALHO, J. G. Inter-relação fertilidade, biologia do solo e nutrição de plantas. Lavras, Sociedade Brasileira de Ciência do Solo, 1999. p. 725-773.

SMITH, S. E.; READ, D. J. Mycorrhizal symbiosis. London, Academic Press, 2008. 787p.

VANDRESSEN, J.; NISHIDATE, F. R.; TOREZAN, J. M. D.; ZANGARO, W. Inoculação de fungos micorrízicos arbusculares e adubação na formação e pós-transplante de mudas de cinco espécies arbóreas nativas do sul do Brasil. Acta Botanica Brasilica, v. 2I, p. 753-765, 2007.

ZANGARO, W.; ALVES, R. A.; LESCANO, L. E. A. M.; ANSANELO, A. P.; NOGUEIRA, M. A. Investment in fine roots and arbuscular mycorrhizal fungi decrease during succession in three Brazilian ecosystems. Biotropica, v. 44 , p. $|4|-150,2012$ a.

ZANGARO, W.; ALVES, R. A.; SOUZA, P. B.; ROSTIROLA, L. V.; LESCANO, L. E. A. M.; RONDINA, A. B. L.; NOGUEI$R A, M$. A. Succession and environmental variation influence soil exploration potential by fine roots and mycorrhizal fungi in an Atlantic ecosystem in southern Brazil. Journal of Tropical Ecology, v. 30, p. 237-248, 2014.

ZANGARO, W.; ANSANELO, A. P.; LESCANO, L. E. A. M.; ALVES, R. A.; RONDINA, A. B. L.; NOGUEIRA, M. A. Infection intensity, spore density and inoculum potential of arbuscular mycorrhizal fungi decrease during secondary succession in tropical Brazilian ecosystems. Journal of Tropical Ecology, v. 28, p. 453-462, 2012b.

ZANGARO, W.; ASSIS, R. L.; ROSTIROLA, L. V.; SOUZA, P. B.; GONÇALVES, M. C.; ANDRADE, G.; NOGUEIRA, M. A. Changes in arbuscular mycorrhizal associations and fine root traits in sites under different plant successional phases in southern Brazil. Mycorrhiza, v. 19, p. 37-45, 2008.

ZANGARO, W.; NISIZAKI, S. M. A.; DOMINGOS, J. C. B.; NAKANO, E. M. Micorriza arbuscular em espécies arbóreas nativas da bacia do rio Tibagi, Paraná. Cerne, v. 8, p. 7787, 2002.

ZANGARO, W.; NISHIDATE, F. R.; CAMARGO, F. R. S.; ROMAGNOLI, G. G.; VANDRESEN, J. Relationship among AM fungi symbiosis, root morphology and seedling growth of tropical native woody species in south Brazil. Journal of Tropical Ecology, v. 21, p. 529-540, 2005.

ZANGARO, W.; NISHIDATE.; F. R.; VANDRESEN, J.; ANDRADE, G.; NOGUEIRA, M. A. Root mycorrhizal colonization and plant responsiveness are related to root plasticity, soil fertility and successional status of native woody species in southern Brazil. Journal of Tropical Ecology, v. 23, p. 53-62, 2007.

ZANGARO, W.; NOGUEIRA, M. A.; ANDRADE, G. Arbuscular mycorrhizal fungi as biofertilizers for revegetation programs. In: RAI, M. K. Current Advances in Fungal Biotechnology. Nova Deli, The Haworth Press, 2009. p. I-28.

ZANGARO, W.; ROSTIROLA, L. V.; SOUZA, P. B.; ALVES, R. A.; LESCANO, L. E. A. M.; RONDINA, A. B. L.; NOGUEIRA, M. A.; CARRENHO, R. 20I3. Root colonization and spore abundance of arbuscular mycorrhizal fungi in distinct successional stages from an Atlantic rainforest biome in southern Brazil. Mycorrhiza, v. 23, p. 22I-233, 2013. 